\title{
Histone Methylation in the Nervous System: Functions and Dysfunctions
}

\author{
Céline Pattaroni • Claire Jacob
}

Received: 17 September 2012 / Accepted: 4 November 2012 /Published online: 17 November 2012

(C) Springer Science+Business Media New York 2012

\begin{abstract}
Chromatin remodeling is a key epigenetic process controlling the regulation of gene transcription. Local changes of chromatin architecture can be achieved by post-translational modifications of histones such as methylation, acetylation, phosphorylation, ubiquitination, sumoylation, and ADP-ribosylation. These changes are dynamic and allow for rapid repression or de-repression of specific target genes. Chromatin remodeling enzymes are largely involved in the control of cellular differentiation, and loss or gain of function is often correlated with pathological events. For these reasons, research on chromatin remodeling enzymes is currently very active and rapidly expanding, these enzymes representing very promising targets for the design of novel therapeutics in different areas of medicine including oncology and neurology. In this review, we focus on histone methylation in the nervous system. We provide an overview on mammalian histone methyltransferases and demethylases and their mechanisms of action, and we discuss their roles in the development of the nervous system and their involvement in neurodevelopmental, neurodegenerative, and behavioral disorders.
\end{abstract}

Keywords Chromatin remodeling $\cdot$ Histone methylation . Nervous system · Development · Differentiation · Disease

\section{Introduction}

In eukaryotes, genetic information is compacted within the nucleus into chromatin. Chromatin is composed of nucleosomes that are themselves formed by DNA wrapped around

\section{Pattaroni $\cdot$ C. Jacob $(\bowtie)$}

Department of Biology, Unit of Zoology, University of Fribourg,

Chemin du musée 10

1700 Fribourg, Switzerland

e-mail: claire.jacob@unifr.ch histone proteins. Chromatin architecture can be rapidly changed by post-translational modifications of residues located on histone tails. These modifications, including methylation, acetylation, phosphorylation, ubiquitination, sumoylation, and ADP-ribosylation, can result in a chromatin structure that is locally either more condensed or more relaxed: A condensed chromatin limits the access for transcription factors to DNA and may lead to transcriptionally inactive regions, whereas a relaxed chromatin facilitates the access for the transcriptional machinery to DNA and is therefore more subject to active transcription. In addition, different histone post-translational modifications can occur simultaneously or subsequently, providing a high degree of complexity in chromatin configurations and thereby allowing for accurate control of gene expression.

In this review, we focus on histone methylation and demethylation. Histone methyltransferases (HMTs) are enzymes that catalyze the addition of methyl groups to target residues of histone tails, while histone demethylases (HDMs) remove these methyl groups. Histone methylation is considered to be very stable as compared with other histone marks that are more dynamic. However, the recent discovery of HDMs [1,2] revealed that histone methylation is a reversible histone mark. Although our knowledge on the specific functional roles of histone methylation enzymes is still limited, recent progress has highlighted their key functions in gene transcription and cell cycle regulation during development and differentiation, DNA damage, and stress response. Furthermore, several studies indicated that histone methylation may be critically involved in disease and aging (reviewed in [3, 4]).

Interestingly, a lot of effort has been recently invested in elucidating the role of histone methylation in the development and differentiation of neural cells. The mammalian nervous system is mainly composed of neurons and glial cells. Oligodendrocytes in the central nervous system (CNS) and 
Schwann cells in the peripheral nervous system (PNS) constitute the myelinating glia that ensheath neurons to provide insulation and fast conduction of electric signals. In addition to myelinating cells, astrocytes and microglia are two other types of glial cells of the CNS involved in different neuronal supporting functions and processes such as inflammation. Sensory neurons and Schwann cells originate from neural crest cells, while other types of neurons, oligodendrocytes, and astrocytes derive from neural stem cells and microglia from hematopoietic stem cells. The specific program of neural development that starts with the specification of precursor cells into distinct neural cell types is controlled by a complex network of transcription factors. In addition, chromatin remodeling enzymes are coordinating the activity of key transcription factors involved in neural development. Indeed, we and others have shown the critical involvement of histone deacetylases (HDACs) 1 and 2 in the development of myelinating cells $[5,6]$. Another good example is the enhancer of Zeste homolog 2 (EZH2) HMT that is required to maintain a proper balance between neural stem cell self-renewal and differentiation into neurons [7] and that also plays a critical role in the differentiation of neural stem cells into oligodendrocytes [8]. Altogether, these findings have emphasized the importance of chromatin remodeling enzymes in the differentiation and maturation of the nervous system.

Beyond a critical involvement in development, chromatin remodeling is very likely to be also implicated in pathologies of the nervous system: Accumulation of specific histone marks correlates with several neurological disorders, and recent studies suggest that histone methylation enzymes are essential to the proper function of the nervous system $[9,10]$.

In this review, we describe the different known mammalian members of histone methyltransferase and demethylase families, their mechanism of action, their critical functions in the development of the nervous system, and their involvement in neurodevelopmental, neurodegenerative, and behavioral disorders.

\section{HMTs and HDMs}

HMTs catalyze the transfer of methyl groups from $S$-adenosylmethionine (SAM) to histones [11]. Three families of HMTs have been described: the SET (Su(var)3-9, enhancer of Zeste, trithorax)-domain-containing proteins [12] and DOT1-like proteins [13] catalyzing the methylation of lysine residues, and the protein arginine $N$-methyltransferases (PRMTs) that methylate arginine residues [14] (Fig. 1).

The removal of methyl groups from lysine residues on histones is catalyzed by HDMs. Two families of lysine HDMs, the amine oxidases [1] and the Jumonji C (JmjC) domain-containing proteins, have been identified (Fig. 1). However, the existence of specific arginine HDMs is not

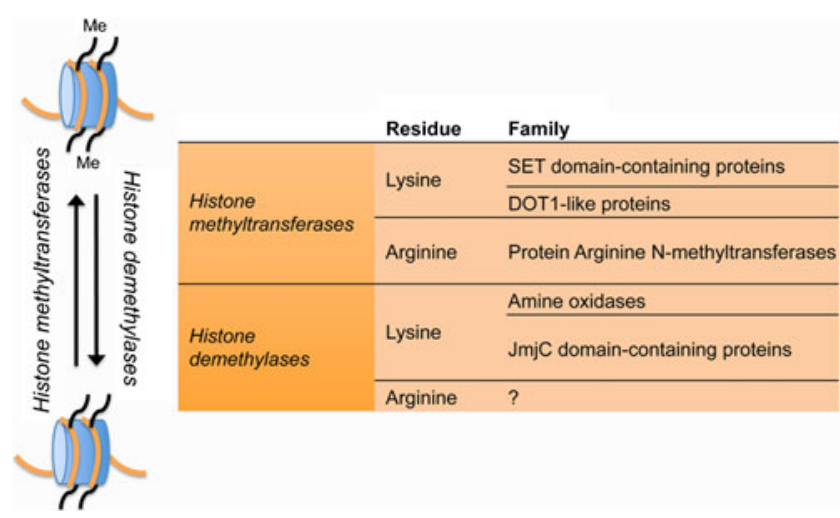

Fig. 1 Histone methyltransferase and demethylase families. Histone methylation is catalyzed by histone methyltransferases that belong to three identified families, while the removal of methyl groups on histone residues is catalyzed by histone demethylases that include two described families of enzymes

clear: The JmjC-domain-containing protein JMJD6 has been shown to demethylate arginines [15], but this enzyme is also a lysyl hydroxylase [16]. Another way for cells to get rid of methylated arginines is to use deiminases that convert arginines into citrullines [17]; however, these enzymes are not able to demethylate arginines.

Structure and Catalytic Mechanisms of Histone Methylation Enzymes

\section{HMTs}

SET-domain-containing HMTs possess, in addition to their SET domain (containing the catalytic core), a pre-SET domain and a post-SET domain that are involved in the methyltransferase activity and specificity of the enzyme. In order to methylate histone tails, the SET domain of HMTs first recognizes lysines and SAM molecules, which are brought in close proximity, then catalyzes the deprotonation of the $\varepsilon$ amino group of the lysine residue by a nearby tyrosine to allow the transfer of the methyl group from the SAM molecule to the lysine residue [18].

In contrast to SET-domain-containing enzymes that target lysine residues on histone tails, Dot1 HMT was shown in budding yeast to only methylate lysine residues in the globular histone core [19]. Dot1-like HMT (DOT1L) homologs have been identified in mammals [13]. A structural study of the catalytic domain of human DOT1L reveals common features with other methyltransferases that do not methylate lysine residues; however, this study identifies a potential binding channel for lysine residues [20]. Further structural studies are still needed to understand the precise catalytic mechanism of this enzyme.

The catalytic domain of PRMTs, consisting of a SAM binding domain and a substrate binding domain, recognizes arginine residues brought in close proximity to SAM 
molecules. Arginine residues are then deprotonated by a nearby glutamate to allow the transfer of the methyl group from the SAM molecule to the arginine residue [21].

For complete review about HMT structures and catalytic mechanisms, see also Wood and Shilatifard [22].

\section{$H D M s$}

Amine oxidases such as LSD1 contain a C-terminal amine oxidase-like domain that includes two subdomains: a FAD-binding subdomain and a substrate-binding subdomain [23]. A large cavity formed by these two subdomains constitutes the catalytic core of the enzyme. LSD1 activity depends on the cofactor FAD. LSD1 catalyzes the transfer of two hydrogens from a methylated lysine to a FAD that is then reduced into $\mathrm{FADH}_{2}$; this reaction eventually results into an unmethylated lysine and a formaldehyde byproduct [1].

JmjC-domain-containing demethylases catalyze hydroxylation reactions. This second family of HDMs introduces a hydroxyl group into a methyl group on a lysine residue using $\mathrm{Fe}(\mathrm{II})$ and $\alpha$-ketoglutarate as cofactors to generate succinate and an unstable carbinol amine intermediate that leads to the formation of an unmethylated lysine and a formaldehyde byproduct $[24,25]$.

\section{Target Residues and Methylation Outcome}

Histone methylation can occur on the three basic residues lysine $(\mathrm{K})$, arginine $(\mathrm{R})$, and histidine; however, histidine methylation is rarely observed. Lysines can be mono- (me1), di- (me2), or trimethylated (me3); arginines can be mono- or dimethylated, whereas only monomethylation of histidine has been described.

Histone methylation sites are mainly located on histones $\mathrm{H} 3$ and H4; however, methylation can also occur on histones $\mathrm{H} 1, \mathrm{H} 2 \mathrm{~A}$, and H2B. The most described methylation sites are listed in Tables 1 and 2. The effect of histone methylation on gene expression activity depends on the location of the methylated residue and can also depend on the degree of methylation and the HMT (whether the enzyme catalyzes symmetric or asymmetric methylation): H3K9, H3K27, H4K20, and H3R8 methylations are described as marks of transcriptional repression (reviewed in [26], [27], and [28]) H3K4 [29, 30], H3K36 (reviewed in [31]), H3K79 (reviewed in [32]), H3R17, and H3R26 (reviewed in [33]) methylations are mostly (but not always, e.g., [29]) associated with active transcription, whereas methylation of H3R2 and H4R3 (reviewed in [33]) can either lead to transcriptional activation or repression, depending on the degree of methylation and/or the type of methyltransferase. The most common effects of currently described HMTs and HDMs are summarized in Tables 1 and 2.
Enzyme Recruitment to Histone Target Residues

Several studies have shown that specific DNA sequences, long non-coding RNAs (lncRNAs), small non-coding RNAs, and DNA methylation could direct histone methylation enzymes to their target sites.

In Drosophila melanogaster, specific DNA sequences including the polycomb group $(\mathrm{PcG})$ response elements (PREs) and the trithorax group response elements are able to recruit histone methylation enzymes such as, respectively, PcG proteins and the H3K4 methyltransferase Trx [34, 35]. In humans, a D11.12 (region between HOXD11 and HOXD12) genomic element with similar recruitment abilities of PcG proteins as compared with Drosophila PREs has been recently identified, suggesting that the recruitment of histone methylation enzymes by specific DNA sequences may as well occur in mammals [36]. In addition, the JmjC protein JARID2 [37] and polycomb-like 2 [38] have been shown to be able to recruit PRC2, a PcG complex having H3K27 trimethylation activity [39].

Several studies have also reported or suggested the ability of lncRNAs to target HMTs and HDMs to regulatory regions of specific genes. Indeed, Hawkins and Morris showed that the suppression of the lncRNA antisense to Oct4-pseudogene 5 in human cells resulted in increased transcription of Oct4 gene and Oct 4 pseudogenes 4 and 5, correlating with loss of the HMT EZH2 at the Oct4 promoter and therefore indicating the requirement of this IncRNA to target EZH2 to Oct4 gene [40]. In addition, the IncRNA HOTAIR has been shown to bind and recruit PRC2 and the demethylase LSD1 [41]. Another study reports the recruitment of the protein complex containing the H3K4 methyltransferase mixed lineage leukemia (MLL) and WD repeat-containing protein 5 (WDR5) by the IncRNA HOTTIP [42].

Small non-coding RNAs including microRNAs, smallinterfering RNAs and Piwi-interacting RNAs have important functions in transposon silencing, formation of pericentromeric heterochromatin [43], and X-chromosome inactivation [44]. They often play the role of inducers of these mechanisms by recruiting HMTs (reviewed in [45]).

Finally, there is often interplay between DNA methylation and histone methylation. The study of Bartke et al. [46] shows that, in some cases, the recruitment of HMTs is enhanced by the presence of DNA methylation, and in other cases, DNA methylation counteracts the recruitment of HMTs.

For a general review addressing this question, see also, Greer and Shi [3].

\section{Complex Formation and Histone Modification Crosstalk}

Changes in chromatin structure often result from a specific combination of post-translational modifications of histones. In many cases, one histone modification serves as a signal for the 
Table 1 Mammalian histone lysine methyltransferases and demethylases and prevalent transcriptional outcome of methylation (reported enzymes and their alternative names in brackets are sorted depending on the target residue and the degree of methylation)

\begin{tabular}{|c|c|c|c|c|}
\hline $\begin{array}{l}\text { Histone and } \\
\text { residue }\end{array}$ & & Methyltransferase & Prevalent methylation outcome & Demethylase \\
\hline \multirow[t]{18}{*}{$\mathrm{H} 3 \mathrm{~K} 4$} & \multirow[t]{6}{*}{ mel } & SETD1A/B (SET1A/B, KMT2F) & Transcriptional activation & LSD1/2 (KDM1A/B) \\
\hline & & ASH1L (KMT2H) & & KDM5B (JARID1B, PLU1) \\
\hline & & MLL1 (KMT2A, TRX1, HRX, ALL1) & Transcriptional activation & NO66 (MAPJD) \\
\hline & & MLL2 (MLL4, KMT2B, KMT2D, ALR) & Transcriptional activation & \\
\hline & & MLL3 (KMT2C) & Transcriptional activation & \\
\hline & & SETD7 (SET7/9, KMT7) & Transcriptional activation & \\
\hline & \multirow[t]{5}{*}{$m e 2$} & SETD1A/B (SET1A/B, KMT2F) & Transcriptional activation & LSD1/2 (KDM1A/B) \\
\hline & & MLL1 (KMT2A, TRX1, HRX, ALL1) & Transcriptional activation & KDM5A (RBP2, RBBP2) \\
\hline & & MLL2 (MLL4, KMT2B, KMT2D, ALR) & Transcriptional activation & KDM5B/D \\
\hline & & MLL3 (KMT2C) & Transcriptional activation & KDM5C (JARID1C, SMCX) \\
\hline & & SMYD3 & Transcriptional activation & NO66 (MAPJD) \\
\hline & \multirow[t]{7}{*}{$m e 3$} & SETD1A/B (SET1A/B, KMT2F) & Transcriptional activation & KDM2B \\
\hline & & ASH1L (KMT2H) & & KDM5A (RBP2, RBBP2) \\
\hline & & MLL1 (KMT2A, TRX1, HRX, ALL1) & Transcriptional activation & KDM5B/D \\
\hline & & MLL2 (MLL4, KMT2B, KMT2D, ALR) & Transcriptional activation & KDM5C (JARID1C, SMCX) \\
\hline & & MLL3 (KMT2C) & Transcriptional activation & NO66 (MAPJD) \\
\hline & & SMYD3 & Transcriptional activation & \\
\hline & & PRDM9 (MEISETZ) & & \\
\hline \multirow[t]{12}{*}{ H3K9 } & \multirow[t]{4}{*}{ mel } & SETDB1 (ESET, KMT1E) & Transcriptional repression & KDM3A/B (JMJD1A/B, JHDM2A/B) \\
\hline & & G9a (EHMT2, KMT1C) & Heterochromatin formation/silencing & PHF8 \\
\hline & & GLP (EHMT1, KMT1D) & & KDM7 (JHDM1D) \\
\hline & & PRDM2 (KMT8) & & \\
\hline & \multirow[t]{5}{*}{$m e 2$} & SUV39H1/2 (KMT1A/B) & & KDM3A/B (JMJD1A/B, JHDM2A/B) \\
\hline & & SETDB1 (ESET, KMT1E) & & KDM3A/B (JMJD1A/B, JHDM2A/B) \\
\hline & & G9a (EHMT2, KMT1C) & Heterochromatin formation/silencing & PHF8 \\
\hline & & GLP (EHMT1, KMT1D) & Heterochromatin formation/silencing & LSD1 (KDM1A) \\
\hline & & PRDM2 (KMT8) & & KDM7 (JHDM1D) \\
\hline & \multirow[t]{3}{*}{ me3 } & SUV39H1/2 (KMT1A/B) & Heterochromatin formation/silencing & KDM3B (JMJD1B, JHDM2B) \\
\hline & & SETDB1 (ESET, KMT1E) & & KDM4A-D (JMJD2A-D, JHDM3A-D) \\
\hline & & PRDM2 (KMT8) & & \\
\hline \multirow[t]{4}{*}{$\mathrm{H} 3 \mathrm{~K} 27$} & mel & & & KMD7 (JHDM1D) \\
\hline & \multirow[t]{2}{*}{$m e 2$} & $\mathrm{EZH} 1 / 2$ & Transcriptional repression & KDM6A/B (UTX/JMJD3) \\
\hline & & & & KDM7 (JHDM1D) \\
\hline & me3 & $\mathrm{EZH} 1 / 2$ & Transcriptional repression & KDM6A/B (UTX/JMJD3) \\
\hline \multirow[t]{8}{*}{$\mathrm{H} 3 \mathrm{~K} 36$} & \multirow[t]{2}{*}{ mel } & SETD2 (KMT3A) & Transcriptional activation & KDM2A/B (JHDM1A/B, FBXL11/10) \\
\hline & & NSD1-3 & & \\
\hline & \multirow[t]{4}{*}{$m e 2$} & NSD1-3 & & KDM2A/B (JHDM1A/B, FBXL11/10) \\
\hline & & SMYD2 & & NO66 (MAPJD) \\
\hline & & SETD2 (KMT3A) & Transcriptional activation & KDM4A-C (JMJD2A-C, JHDM3A-C) \\
\hline & & ASH1L & & \\
\hline & \multirow[t]{2}{*}{ me3 } & SETD2 (KMT3A) & Transcriptional activation & NO66 (MAPJD) \\
\hline & & & & KDM4A-C (JMJD2A-C, JHDM3A-C) \\
\hline \multirow[t]{3}{*}{ H3K79 } & mel & DOT1L (KMT4) & Transcriptional activation & \\
\hline & $m e 2$ & DOT1L (KMT4) & Transcriptional activation & \\
\hline & me3 & DOT1L (KMT4) & Transcriptional activation & \\
\hline \multirow[t]{3}{*}{$\mathrm{H} 4 \mathrm{~K} 20$} & mel & SETD8 (SET8, KMT5A) & Transcriptional repression & PHF8 \\
\hline & $m e 2$ & SUV420H1/2 (KMT5B/C) & & \\
\hline & me3 & $\begin{array}{l}\text { NSD1 } \\
\text { SUV420H1/2 (KMT5B/C) }\end{array}$ & & \\
\hline
\end{tabular}


Table 2 Mammalian histone arginine methyltransferases and prevalent transcriptional outcome of methylation

\begin{tabular}{llll}
\hline Histone and residue & & Methyltransferase & Prevalent methylation outcome \\
\hline H3R2 & me1 & PRMT4 (CARM1) & Transcriptional activation \\
& & Transcriptional repression \\
& & PRMT6 & \\
& PRMT4 (CARM1) & Transcriptional activation \\
& & PRMT6 & Transcriptional repression \\
H3R8 & PRMT5/7 & \\
H3R17 & PRMT5 (SKB1) & Transcriptional repression \\
& PRMT5 (SKB1) & Transcriptional repression \\
H3R26 & PRMT4 (CARM1) & Transcriptional activation \\
H4R3 & PRMT4 (CARM1) & Transcriptional activation \\
& me1 & PRMT4 (CARM1) & \\
& PRMT4 (CARM1) & \\
& PRMT1 (HMT2) & Transcriptional activation \\
& & PRMT5 (SKB1) & Transcriptional repression \\
& PRMT6/7 & \\
& PRMT1 (HMT2) & PRMT5 (SKB1) & Transcriptional repression \\
& & PRMT6/8 & Transcriptional activation \\
& & PRMT7 & \\
& & &
\end{tabular}

assembly of protein complexes containing several histonemodifying enzymes. HMTs and/or HDMs are frequently found in these protein complexes. Because of the particular role of histone acetylation and deacetylation in chromatin dynamics of the nervous system, we will focus on the protein complexes containing HMTs or HDMs and histone acetyltransferases (HATs) or HDACs. The PRC2 complex containing EZH2 has also a key role in the development of nerve cells and will be therefore described in this section.

\section{H3K4 HMT Complexes}

Most MLL HMTs targeting H3K4 act within multiprotein complexes that contain a three-subunit core composed of WDR5, RbBP5, and ASH2L, necessary for the methyltransferase activity [47]. The MLL1 complex, a key regulator of Hox genes during development, contains also the H4K16 HATs MOF/KAT8 [48] or MOZ [49] and other cofactors that act together to regulate transcription initiation and elongation [50-53]. The activity of this MLL complex is stimulated by the acetylation of $\mathrm{H} 3 \mathrm{~K} 9$ or $\mathrm{H} 3 \mathrm{~K} 14$ [50], demonstrating the critical role of crosstalk between different histone modifications for the regulation of target genes.

\section{H3K9 HMT Complexes}

In contrast to MLL HMTs, SETDB1 HMT targets H3K9 residue to induce gene silencing or heterochromatin formation. SETDB1 can robustly methylate unmodified histone
H3, whereas acetylation of H3K9 or H3K14 strongly inhibits SETDB1 activity. For this reason, SETDB1 HMT needs to act in concert with a deacetylase complex. Consistent with this, SETDB1 interacts with the co-repressor KAP-1 that serves as a scaffold for KRAB zinc-finger proteins that target the protein complex to specific promoters, for the NuRD complex (containing HDAC1 and HDAC2) required for deacetylation of histone H3, and for HP1 (heterochromatin protein 1) that allows formation of heterochromatin $[54,55]$.

Similarly to SETDB1, Suv39H1 HMT recruits HP1 by methylating $\mathrm{H} 3 \mathrm{~K} 9$ and is involved in heterochromatin formation and in transcriptional repression. Suv39H1, such as SETDB1, functionally interacts with HDAC1 or HDAC1/2 $[56,57]$.

G9a HMT also targets H3K9. G9a plays a critical role in transcriptional repression, and studies in mice revealed that this HMT is essential for early embryonic development [58]. G9a recruits HP1 and has been shown to associate with transcriptional repressors such as HDAC1/2 and DNA methyltransferases [59, 60].

\section{H3K27 HMT Complexes}

The polycomb repressive complex PRC2 induces gene silencing by the di- and trimethylation of $\mathrm{H} 3 \mathrm{~K} 27$ catalyzed by the HMTs EZH2 or EZH1 $([39,61]$ and reviewed in Margueron and Reinberg [62]). PRC2 can also methylate H3K9 and $\mathrm{H} 1 \mathrm{~K} 26$, which leads to the recruitment of the PRC1 complex that represses genes through monoubiquitylation of 
histone H2A [63]. PRC2 comprises four core components that are required for its activity: EZH1/2, embryonic ectoderm development protein (EED), RbAp46/48, and SUZ12 (suppressor of Zeste 12 homolog). EZH2 and EZH1 are both able to methylate H3K27; however, EZH1 has lower methyltransferase activity than EZH2 [64]. EED and $\mathrm{RbAp} 46 / 48$ are both WD40 repeat containing proteins. EED allows recognition of the $\mathrm{H} 3$ substrate by PRC2 [65] and the propagation of $\mathrm{H} 3 \mathrm{~K} 27$ methylation [66] while RbAp46/48, which can bind histone H3, SUZ12, and histone $\mathrm{H} 4$, may be involved in substrate specificity [39]. SUZ12 contains a zinc-finger domain that is important for the recruitment of PRC2 to its target genes [67, 68]. Beyond these four core components, other proteins are found in PRC2 complexes: the zinc-finger protein AEBP2, the polycomb-like protein PCL1 (also known as PHF1), and the Jumonji protein JARID2. These three proteins are involved in the regulation and enhancement of PRC2 activity and in the recruitment of the complex [69-71]. PRC2 is required for $\mathrm{X}$ inactivation and silencing of Hox gene expression during embryonic development and has key functions in stem cell self-renewal, but also in lineage commitment and maintenance of cellular identity [reviewed in Margueron and Reinberg and Walker et al. 62, 72].

\section{HDM Complexes}

The first described histone demethylase LSD1 that can target methylated $\mathrm{H} 3 \mathrm{~K} 4$ or $\mathrm{H} 3 \mathrm{~K} 9$ is involved in diverse molecular interactions. LSD1 has been initially found to be part of the repressive CoREST complex, which also consists of HDAC1/2, BHC80, and BRAF35 [1, 73]. Additionally, other studies revealed that the CoREST complex is part of another transcriptional corepressor complex, CtBP, which also contains G9a and GLP HMTs and other cofactors [74]. Finally, LSD1 has also been identified as a component of the NuRD complex, where it also acts as transcriptional repressor by demethylating $\mathrm{H} 3 \mathrm{~K} 4$. The NuRD complex exhibits an ATP-dependent chromatin remodeling activity, together with the presence of HDAC1/ 2, Mi-2 and histone-binding proteins [75].

NCoR protein, which is known to act within a multimeric protein complex involved in development and neural differentiation, has also been shown to associate with HDMs. Indeed, a repressive complex containing NCoR protein, REST, and HDAC1/2 was found to be associated to G9a HMT and KDM5C, a demethylase of $\mathrm{H} 3 \mathrm{~K} 4 \mathrm{me} 2$ and $\mathrm{H} 3 \mathrm{~K} 4 \mathrm{me} 3$ [76]. Another HDM, KDM4A, that demethylates H3K36, seems to be required in the NCoR complex for selective repression of Ascl2 gene, a basic helix-loop-helix transcription factor essential for proper placental development [77].

Finally, the highly conserved Sin3-HDAC complex, which regulates many genes and has fundamental roles in development, has been shown to associate with the H3K4 HDM KDM5A. This Sin3 complex is constituted of HDAC1/2, Sin3A or Sin3B, RbAp46/48, and SAP18/30, together with other factors such as MRG15, which is involved in the recruitment of KDM5A [78].

As mentioned previously, we only referred to literature that described HMTs or HDMs in complex with HATs or HDACs and to the PRC2 complex. Other important interactions, such as HDMs with nuclear hormone receptors [79, 80], have also been described but are not discussed here.

\section{Histone Methylation in the Nervous System}

We and others have shown that several members of the HDAC family are crucial for the development of myelinating cells (reviewed in Jacob et al. [6]). Because HMTs and HDMs are often found in multiprotein complexes where HDACs are present and play an essential role in the activity of these complexes, it is very likely that histone methylation enzymes and HDACs have coordinated functions in the development of the nervous system. In this section, we will first discuss the functions of histone methylation in the development and differentiation processes of nerve cells, including neurons, oligodendrocytes, and Schwann cells, the myelinating cells of the CNS and PNS, respectively, and astrocytes and microglia, two other important types of glial cells in the CNS. As mentioned before, sensory neurons and Schwann cells originate from neural crest cells while other neurons, oligodendrocytes, and astrocytes originate from neural stem cells and microglia are generated from hematopoietic stem cells. Beyond a key involvement in development, histone methylation is very likely to play important roles in diseases of the nervous system. The second part of this section will be focused on suggested implications of histone methylation in neurodevelopmental and neurodegenerative diseases and in behavioral disorders.

Histone Methylation in the Development and Differentiation of the Nervous System

\section{Neurons}

Much more information is available regarding the role of histone methylation in neurogenesis, as compared with the differentiation process of other cells of the nervous system. The methylation status of $\mathrm{H} 3 \mathrm{~K} 27$ is a key determinant of cell fate during neural lineage progression from neural stem cells [8]. Consistent with this, JMJD3, an H3K27me3 demethylase, induces expression of neuronal genes such as Dlx5, Gad1/2, and Dcx [81]. Additionally, studies on embryonic stem cells also demonstrated that JMJD3 is required for commitment to the neuronal lineage [82] and activation of 
TGFbeta-responsive genes in neurons [83]. However, methylation of $\mathrm{H} 3 \mathrm{~K} 27$ by EZH2 in neural stem cells is required to maintain a proper balance between self-renewal of neural stem cells and differentiation into neurons and to prevent massive neurogenesis and depletion of the neural stem cell pool that would eventually result in a decreased number of neurons [7]. Moreover, the nuclear coreceptor SMRT, repressing the expression of JMJD3, is critical for forebrain development and maintenance of the neural stem cell state [81].

Histone methylation at $\mathrm{H} 3 \mathrm{~K} 4$ has also been shown to play a role in neurogenesis. Indeed, the H3K4 HMT MLL1 promotes neurogenesis in the subventricular zone of the mouse postnatal brain by promoting the expression of Dlx2, a homeodomain-containing transcription factor critical for olfactory bulb interneuron development and migration [84]. Another study in mice revealed that a complex containing MLL2, MLL3, and PTIP is necessary to maintain H3K4 methylation in the neural tube during embryonic development [85]. Consistent with this, the H3K4 HDM KDM5C that acts as a transcriptional repressor has been shown to associate with the REST complex, which represses neuronal genes in non-neuronal tissues. The complex KDM5C and REST associates at a subset of REST-target genes and depletion of KDM5C induces de-repression of several of these target genes [76], suggesting that KDM5C contributes to REST-mediated neuronal gene regulation. In addition to maintaining silencing of neuronal genes in nonneuronal cells, the REST complex is also involved in the differentiation into neurons: The activation of most neuronal genes (designed as class 1) in post-mitotic neurons is only dependent on the release of the REST repressor complex from these genes at the RE1 binding motif, while a smaller group of neuronal genes (designed as class 2) including $B d n f$ remains initially expressed at low levels upon differentiation into neurons even after the release of the REST complex. This is due to the presence of the CoREST and MeCP2 repressor complex on these genes, which is eventually released later by membrane depolarization [86]. The study of Abrajano et al. comparing the different profiles of REST and CoREST target genes in distinct subtypes of neurons shows that the differential presence of these two repressor complexes allows the induction and maintenance of neuronal subtype identity [87].

The status of H3K9 methylation seems also to be involved in neuronal differentiation and in particular in neurite outgrowth. Indeed, Sen and Snyder showed that BDNF, by activating neuronal nitric oxide synthase, induces the degradation of the H3K9 HMT SUV39H1, resulting in the decrease of H3K9 methylation and subsequent increase of H3K9 acetylation. This facilitates CREB binding to DNA and enhances CREB-regulated genes and neurite outgrowth
[88]. Consistently, the H3K9/H4K20 HDM PHF8 has been shown to be essential in neurons to promote cytoskeleton dynamics resulting in neurite outgrowth [89]. H3K9 methylation needs to be decreased for neurite outgrowth; however, this histone mark seems necessary for early neurogenesis. Indeed, ablation of the H3K9 HMT SETDB1 in neural stem cells leads to enhanced formation of astrocytes and severe decrease of early born neurons [90]. The authors of this study show that SETDB1 represses the expression of astrocytic genes and thereby prevents precocious differentiation of neural stem cells into the astrocytic lineage. This mechanism could be required for upregulation of neuronal genes and early neurogenesis.

Interestingly, a recent expression study comparing human cortical neurons to neural progenitor cells reports the transcriptional regulation of many chromatin modifiers during human neurodevelopment and identifies the arginine HMT PRMT8 and the lysine HMT EZH1 as new markers of postmitotic neurons [91].

\section{Oligodendrocytes}

Interesting findings on the implication of histone methylation in the development of myelinating cells have just started to emerge.

Histone methylation has been shown to play a critical role in the specification of the oligodendrocyte lineage from neural stem cells. Indeed, the HMT EZH2 is needed for proper in vitro specification of mouse neural stem cells into oligodendrocytes. While EZH2 is highly expressed in proliferating neural stem cells, its expression is decreased upon differentiation into neurons and abolished during differentiation into astrocytes. However, EZH2 expression remains high in oligodendrocytes [8]. A comparative ChIP-Seq analysis of EZH2 target genes in neural stem cells and in premyelinating oligodendrocytes (pOLs) reports the presence of EZH2 at oligodendrocyte, neuronal, and astrocytic lineage-specific genes in neural stem cells, whereas, in pOLs, EZH2 is not anymore present on the oligodendrocyte lineage-specific genes but is still found on astrocytic and neuronal lineage-specific genes [92].

Histone methylation may also play a role in oligodendrocyte development at later stages, from oligodendrocyte progenitor cells into mature myelinating cells. Interestingly, an increase of the repressive histone mark H3K9me3 and HP $1 \alpha$, a marker of stable chromatin compaction, has been observed in mature oligodendrocytes of the rat corpus callosum [93]. This suggests a possible role of histone methylation in maintaining oligodendrocytes in a differentiated myelinating stage, but the underlying mechanisms and enzymes involved in this process remain unknown.

Finally, the REST and CoREST complexes that repress the transcriptional activity of neuronal genes in non- 
neuronal cells are also necessary for the differentiation process of oligodendrocytes. Similar to their study in neurons, Abrajano et al. have compared the profiles of REST and CoREST target genes during the different stages of oligodendrocyte development [94].

\section{Schwann Cells}

There was no information available about the potential role of histone methylation in Schwann cell differentiation until Heinen et al. recently showed that EZH2 is required for Schwann cell maturation [95]. Indeed, suppression of EZH2 in Schwann cell cultures and dorsal root ganglia cultures leads to the downregulation of myelin genes (P0, PMP22, and MAL) and reduction of process extension. EZH2 binds to and represses the promoter of the cyclindependent kinase inhibitor p57kip2 and thereby downregulates the expression of transcriptional repressors of myelin genes such as Hes5 [95]. The same authors of this study previously demonstrated that $\mathrm{p} 57 \mathrm{kip} 2$ is a negative regulator of Schwann cell differentiation and in vitro myelination [96]. Altogether, these results suggest that EZH2 activity within the PRC2 complex is necessary to initiate suppression of differentiation inhibitors in Schwann cells, therefore allowing Schwann cell differentiation and maturation.

\section{Astrocytes}

As with myelinating cells, little is known about the role of histone methylation in astrocyte development and differentiation. We previously mentioned that EZH2 expression in neural stem cells is downregulated upon differentiation into neurons and abolished during differentiation into astrocytes [8]. Interestingly, important changes in $\mathrm{H} 3$ methylation have been observed on the promoter of the Gfap gene, a marker of the astrocytic lineage. Indeed, fibroblast growth factor 2 (FGF2) has been shown to induce $\mathrm{H} 3 \mathrm{~K} 4$ methylation and to reduce H3K9 methylation on the Gfap promoter. This facilitates the access of the STAT/CBP complex to the Gfap promoter and allows ciliary neurotrophic factor-mediated astrocyte differentiation [97]. However, the underlying mechanism of HMTs and/or HDMs recruitment by FGF2 has not been elucidated yet. Consistently and as mentioned earlier, the H3K9 HMT SETDB1 represses astrocytic genes in neural stem cells and ablation of SETDB1 results in increased astrogenesis [90].

\section{Microglia}

Unfortunately, there is currently no evidence concerning the role of histone methylation in microglia development or differentiation. However, some studies reported an implication of histone methylation enzymes in the inflammatory response and the establishment of HIV-1 latency in microglia. Indeed, microglial cells are the principal targets of HIV-1 in the nervous system and constitute a latent reservoir for the virus [98]. Some studies demonstrated a recruitment of a chromatin-modifying complex containing HDAC $1 / 2$ and the H3K9 HMT SUV39H1 by the corepressor COUP-TF interacting protein 2 (CTIP2) at the viral promoter of HIV-1 in microglia [99]. The authors also demonstrated that this complex associates with the promoter of the cyclin-dependent kinase inhibitor $p 21$, whose expression is affected in HIV-1 infected microglia [100]. Additionally, they showed that the HDM LSD1 can also interact with CTIP2 to silence HIV-1 promoter [101]. Altogether, these repressive complexes may thus participate in the maintenance of HIV-1 latency in microglia.

In a different context, the CoREST repressor complex containing G9a HMT and LSD1 HDM is recruited by the orphean nuclear receptor Nurr1 to repress the promoters of inflammatory target genes [102]. Since the Nurrl/CoREST complex exerts a regulatory role on inflammatory gene expression, it is likely that histone methylation could play a potential role in the control of inflammation in microglial cells.

Reported functions of histone methylation in the development and differentiation processes of neurons, myelinating cells, and astrocytes are summarized in Table 3 and illustrated in Figs. 2, 3, and 4.

Nervous System Disorders Related to Histone Methylation

As mentioned earlier, accumulations of several histone modifications including methylation have been shown to correlate with neurological disorders. These modifications vary from one disorder to another, and it is not always clear whether they are a cause or a consequence of the disease. Understanding the mechanisms underlying these histone modifications observed in pathological conditions is of utmost importance for the design of novel therapeutic treatments. The following section focuses on recent findings related to histone methylation processes that have been correlated to neurodevelopmental and neurodegenerative diseases and behavioral disorders (summarized in Table 4).

\section{Neurodevelopmental Diseases}

Mutations of H3K4 KDM5C [103-107] and of H3K9/ H4K20 PHF8 [108-110] HDMs have been linked to mental retardation (for KDM5C and PHF8) and facial deformity (for PHF8) in humans. The genes encoding these two HDMs are located on the $\mathrm{X}$ chromosome, where genes affecting cognitive functions seem to be more represented when compared with autosomes. Interestingly, these neurologic phenotypes are consistent with the expression patterns identified in mouse brains. Indeed, KDM5C is highly 
Table 3 Functions of histone methylation enzymes in the development and differentiation of neural cells

\begin{tabular}{|c|c|c|c|c|c|c|}
\hline Cell type & $\begin{array}{l}\text { Target } \\
\text { residue }\end{array}$ & Enzyme & Modification & Observation & Suggested role & References \\
\hline \multirow[t]{9}{*}{ Neurons } & \multirow[t]{3}{*}{ H3K27 } & $\begin{array}{l}\text { KDM6B } \\
\text { (JMJD3) }\end{array}$ & Demethylation & $\begin{array}{l}\text { Neuronal genes induced } \\
\text { when JMJD3 is overexpressed } \\
\text { in neural stem cells }\end{array}$ & $\begin{array}{l}\text { Promotes differentiation of neural } \\
\text { stem cells into neurons }\end{array}$ & [81-83] \\
\hline & & EZH2 & Methylation & $\begin{array}{l}\text { Upregulation of genes involved } \\
\text { in neurogenesis in Ezh2-null } \\
\text { mouse cortex }\end{array}$ & $\begin{array}{l}\text { Maintenance of appropriate balance } \\
\text { between neural stem cell } \\
\text { self-renewal } \\
\text { and differentiation into neurons }\end{array}$ & {$[7]$} \\
\hline & & EZH1 & Methylation & $\begin{array}{l}\text { High expression in } \\
\text { post-mitotic neurons }\end{array}$ & & [91] \\
\hline & \multirow[t]{2}{*}{$\mathrm{H} 3 \mathrm{~K} 4$} & MLL1 & Methylation & $\begin{array}{l}\text { Neurogenesis impaired in the } \\
\text { absence of MLL1 in mouse } \\
\text { subventricular zone (SVZ) }\end{array}$ & $\begin{array}{l}\text { Induces postnatal neurogenesis in the } \\
\text { SVZ via transcriptional activation of } \\
\text { Dlx2 }\end{array}$ & {$[84]$} \\
\hline & & $\begin{array}{l}\text { KDM5C } \\
\text { (SMCX) }\end{array}$ & Demethylation & $\begin{array}{l}\text { KDM5C and REST are released } \\
\text { from RE1 binding sites upon } \\
\text { differentiation into neurons }\end{array}$ & $\begin{array}{l}\text { Cell identity establishment by } \\
\text { REST-mediated silencing of neuro- } \\
\text { nal genes in non-neuronal cells and } \\
\text { de-repression of neuronal genes by } \\
\text { relase of REST for differentiation } \\
\text { into neurons }\end{array}$ & {$[76]$} \\
\hline & \multirow[t]{2}{*}{ H3K9 } & SETDB1 & methylation & $\begin{array}{l}\text { Early neurogenesis severely } \\
\text { impaired and increased } \\
\text { astrogenesis in the absence of } \\
\text { SETDB1 }\end{array}$ & $\begin{array}{l}\text { Represses astrocytic genes to prevent } \\
\text { precocious differentiation in } \\
\text { astrocytes and to allow } \\
\text { differentiation } \\
\text { of early-born neurons }\end{array}$ & {$[90]$} \\
\hline & & SUV39H1 & Methylation & $\begin{array}{l}\text { Downregulation of SUV39H1 } \\
\text { induced by BDNF enhances } \\
\text { CREB-related genes }\end{array}$ & $\begin{array}{l}\text { Neurite outgrowth promoted by } \\
\text { downregulation of SUV } 39 \mathrm{H} 1 \text { and } \\
\text { subsequent decrease of } \mathrm{H} 3 \mathrm{~K} 9 \\
\text { methylation }\end{array}$ & {$[88]$} \\
\hline & $\begin{array}{l}\mathrm{H} 3 \mathrm{~K} 9 / \\
\mathrm{H} 4 \mathrm{~K} 20\end{array}$ & PHF8 & Demethylation & $\begin{array}{l}\text { Activation of genes involved in } \\
\text { cytoskeleton dynamics }\end{array}$ & Neurite outgrowth & [89] \\
\hline & H4R3 & PRMT8 & Methylation & $\begin{array}{l}\text { Hig hexpression in post-mitotic } \\
\text { neurons }\end{array}$ & & [91] \\
\hline \multirow[t]{2}{*}{ Oligodendrocytes } & H3K27 & EZH2 & Methylation & $\begin{array}{l}\text { EZH2 remains highly expressed } \\
\text { in } \\
\text { oligodendrocytic lineage } \\
\text { where } \\
\text { it represses astrocytic and } \\
\text { neuronal lineages specific } \\
\text { genes }\end{array}$ & $\begin{array}{l}\text { Cell fate choice towards } \\
\text { oligodendrocytic lineage upon } \\
\text { induction of neural stem cell } \\
\text { differentiation and maintenance of } \\
\text { oligodendrocyte lineage identity }\end{array}$ & {$[8,92]$} \\
\hline & H3K9 & $\begin{array}{l}\text { not } \\
\text { described }\end{array}$ & Methylation & $\begin{array}{l}\text { Increase of } \mathrm{H} 3 \mathrm{~K} 9 \mathrm{me} 3 \text { and } \mathrm{HP} 1 \alpha \\
\text { levels in mature } \\
\text { oligodendrocytes }\end{array}$ & $\begin{array}{l}\text { Maintenance of oligodendrocytes } \\
\text { myelination }\end{array}$ & [93] \\
\hline Schwann cells & H3K27 & $\mathrm{EZH} 2$ & Methylation & $\begin{array}{l}\text { Decrease of myelin gene } \\
\text { expression and process } \\
\text { extension in Schwann cells } \\
\text { upon downregulation of EZH2 }\end{array}$ & $\begin{array}{l}\text { Promotes Schwann cell maturation by } \\
\text { repressing p57kip2, what } \\
\text { downregulates inhibitors of } \\
\text { myelination such as Hes5 }\end{array}$ & {$[95]$} \\
\hline \multirow[t]{2}{*}{ Astrocytes } & H3K4 & $\begin{array}{l}\text { SETD7 } \\
\text { (SET7/9) }\end{array}$ & Methylation & $\begin{array}{l}\text { Increased } \mathrm{H} 3 \mathrm{~K} 4 \text { methylation on } \\
\text { the GFAP promoter }\end{array}$ & $\begin{array}{l}\text { Mediates FGF2-dependent astrocyte } \\
\text { differentiation via the transcriptional } \\
\text { activation of GFAP }\end{array}$ & {$[97]$} \\
\hline & H3K9 & $\begin{array}{l}\text { Not } \\
\text { described }\end{array}$ & Demethylation & $\begin{array}{l}\text { Decreased } \mathrm{H} 3 \mathrm{~K} 9 \\
\text { methylation on } \\
\text { the GFAP promoter }\end{array}$ & $\begin{array}{l}\text { Mediates FGF2-dependent astrocyte } \\
\text { differentiation via the de-repression } \\
\text { of GFAP gene }\end{array}$ & {$[97]$} \\
\hline
\end{tabular}

expressed and seems to have important functions in brain regions involved in cognition such as the hippocampus [125]. Some studies performed in zebrafish, and primary mammalian neurons showed that these phenotypes could be due to disrupted brain development. Indeed, neuronal survival and dendritic development are affected by mutation of KDM5C [126]. Concerning PHF8, a role for this HDM in zebrafish neuronal cell survival and craniofacial development has been identified [127], providing new insights into the related human pathology.

The Kleefstra syndrome, caused by either deleterious mutations or haploinsufficiency of the H3K9 HMT EHMT1 [111], includes mental retardation and other developmental defects. Interestingly, heterozygous Ehmt1 knockout mice 


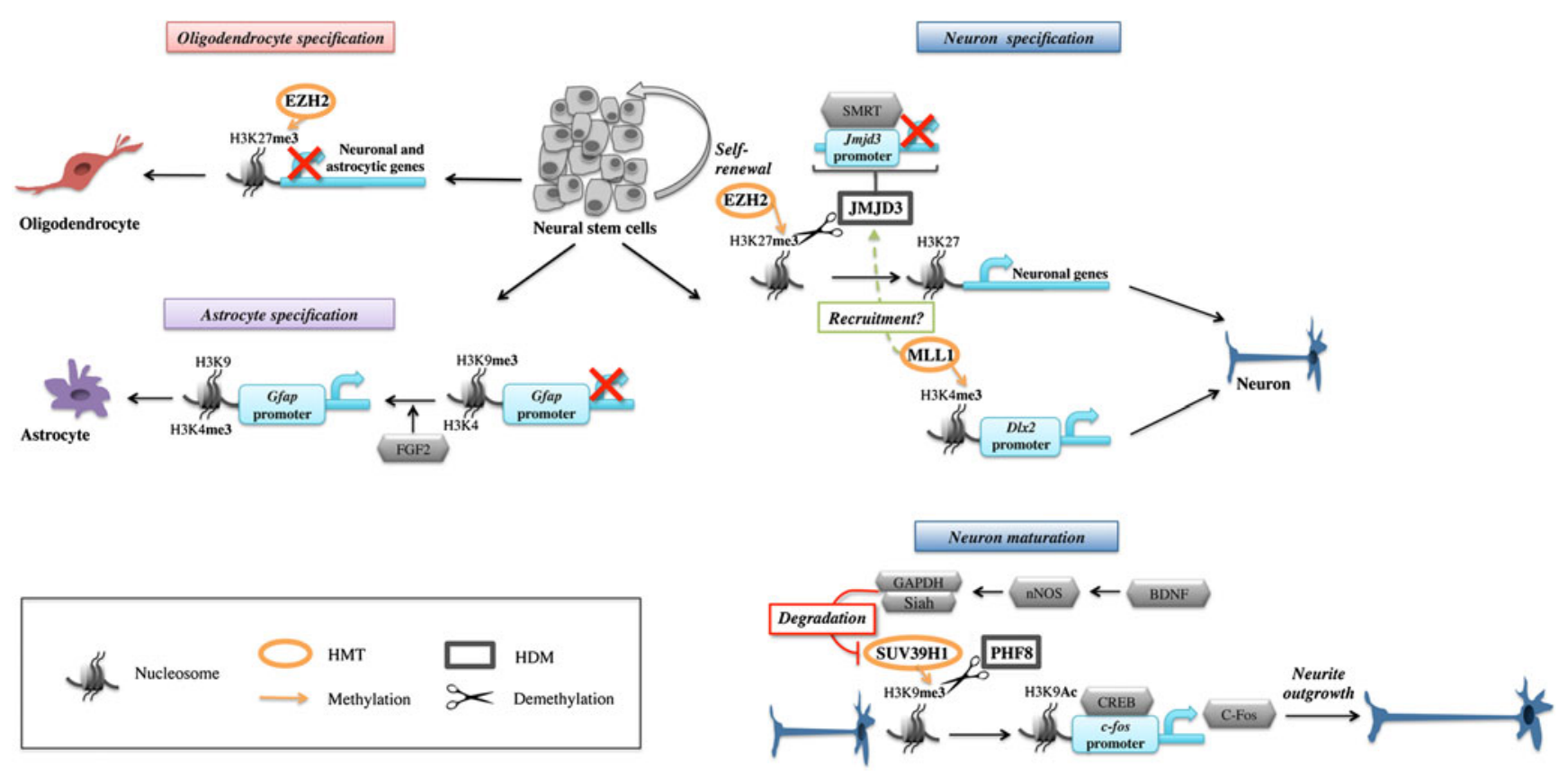

Fig. 2 Known functions of histone methyltransferases and demethylases in the specification and differentiation of neurons, oligodendrocytes, and astrocytes

develop autistic-like behavior that resembles the human pathology [128]. EHMT1 is part of a multiprotein complex that also includes the H3K9 HMT G9a as well as other methyltransferases [129]. Conditional mutagenesis of Ehmt1 and G9a in postnatal mouse brain revealed the importance of this complex for the silencing of non-neuronal genes and progenitor genes in mature neurons. Furthermore, absence of the EHMT1/G9a complex has detrimental effects on cognition and other higher brain functions [130].

\section{Neurodegenerative Diseases}

Aberrant histone modifications related to methylation have been detected in Friedreich ataxia, Huntington's disease, and Alzheimer disease (AD), three neurodegenerative diseases of the CNS. Friedreich ataxia is an autosomal neurodegenerative disorder caused by abnormally high copy numbers of GAA repeats in the frataxin gene [131]. Interestingly, analyses of human brain tissues revealed increased

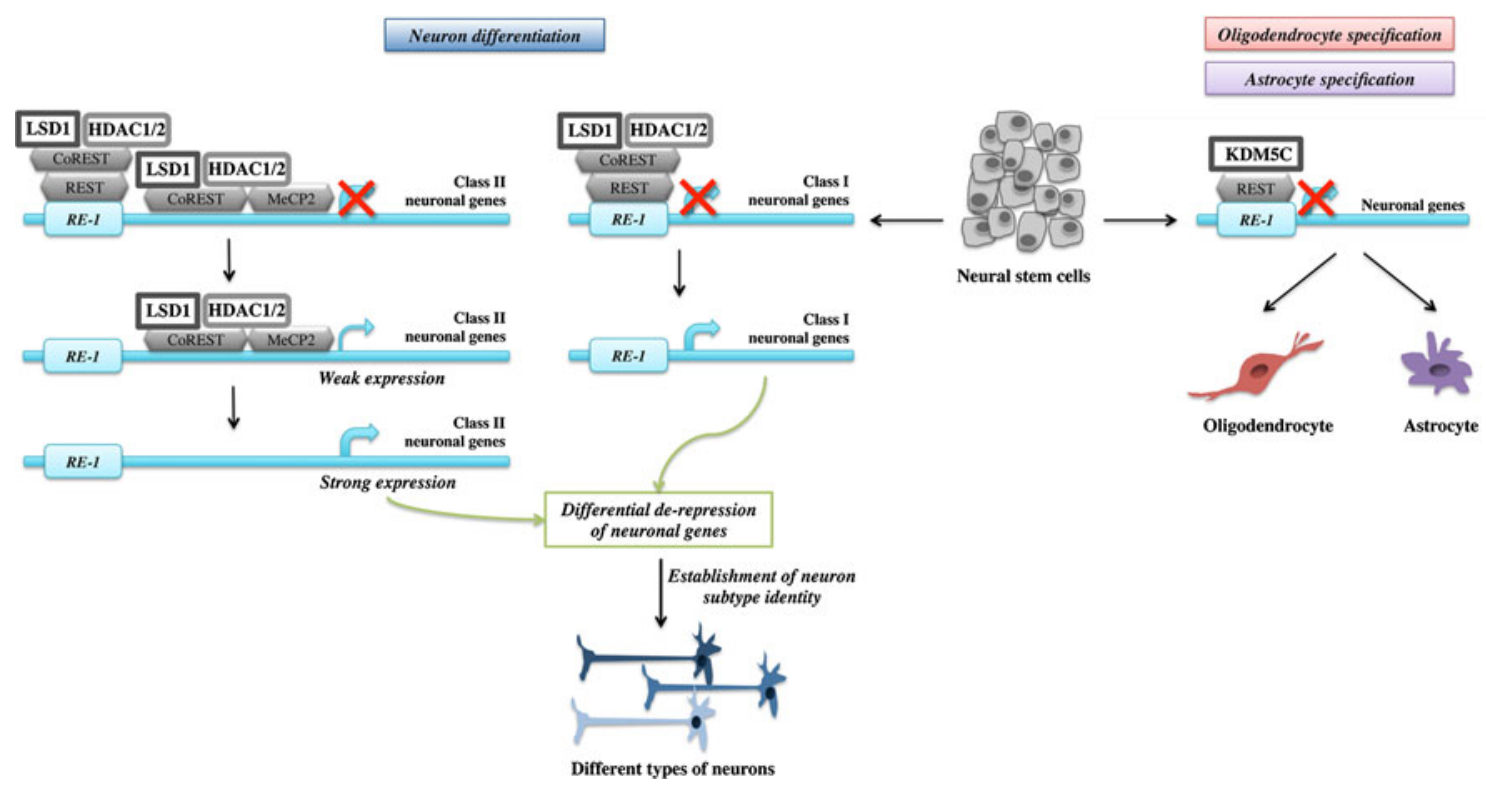

Fig. 3 Functions of REST and CoREST complexes in the specification and differentiation of neurons, oligodendrocytes, and astrocytes. Note that other proteins such as BHC 80 and BRAF35 also belong to the
CoREST complex, and the HMT G9a can also be associated with REST, but to simplify the figure, these proteins are not represented here 


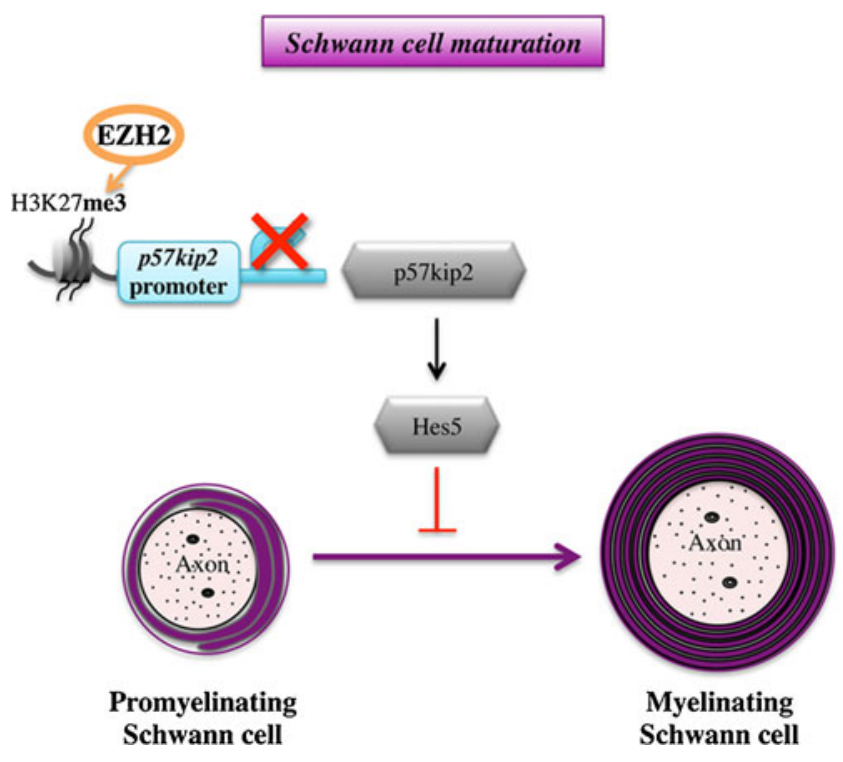

Fig. 4 Role of EZH2 in Schwann cell differentiation

levels of $\mathrm{H} 3 \mathrm{~K} 9$ methylation together with decreased histone acetylation at the frataxin gene, resulting in transcriptional repression of this gene [9].

Similarly, high levels of methylated H3K9 and its corresponding SETDB1 HMT have been detected in postmortem human striatal tissues of patients suffering from Huntington's disease. Huntington's disease is caused by a mutation in the huntingtin gene that creates an expansion of a CAG trinucleotide repeat encoding poly-glutamine [112]. Mutated huntingtin interferes with the normal function of neuroprotective factors such as Sp1 and CREB-binding protein, which renders mutated huntingtin neurotoxic [132-134].

Increased levels of H3K9 trimethylation have also been detected in the postmortem brain of a patient suffering from $\mathrm{AD}$, as compared with the levels of $\mathrm{H} 3 \mathrm{~K} 9 \mathrm{me} 3$ detected in the brain of his twin brother that did not suffer from $A D$ [113]. AD is linked to age-related changes in the metabolism of beta-amyloid $(A \beta)$ precursor protein and tau protein, resulting in aggregates of $A \beta$ fibrils and neurofibrillary tangles that may impact neuronal integrity (reviewed in Huang et al. [135]). The increased H3K9me3 in human brain described above seems rather anecdotic; however, studies in a transgenic mouse model of AD also showed an increase of histone $\mathrm{H} 3$ methylation in the presence of $\mathrm{A} \beta$ in the prefrontal cortex of these mice [114].

Finally, we can mention the progressive decline of histone methylation marks in oligodendrocytes during aging, which is associated with increased histone acetylation and re-expression of inhibitors of myelin proteins [115]. This loss of histone methylation could play a role in the decreased efficiency of remyelination during aging [116].

\section{Behavioral Disorders}

Different histone methylation marks have been associated with behavioral disorders. This topic has been recently extensively reviewed elsewhere [10]. In this section, we have therefore briefly pointed out the most important findings. $\mathrm{H} 3 \mathrm{~K} 27, \mathrm{H} 3 \mathrm{~K} 9$, and $\mathrm{H} 3 \mathrm{~K} 4$ methylation marks have been shown to play a role in the development of mood disorders and depression-like behaviors in mice. BDNF is involved in the adaptation of the hippocampus to stress [136], and histone methylation could be part of the regulatory mechanisms mediating its expression. Interestingly, chronic defeat stress induces H3K27 methylation at the Bdnf gene in mouse hippocampus, leading to transcriptional repression [117]. Consistent with these results, mice exposed to environmental enrichment demonstrated a strong increase in BDNF mRNA expression in hippocampus, associated with decreased $\mathrm{H} 3 \mathrm{~K} 27$ and $\mathrm{H} 3 \mathrm{~K} 9$ methylation together with increased H3K4 methylation [118]. Additionally, studies about global histone methylation in rat dentate gyrus during acute and chronic stress revealed important changes in $\mathrm{H} 3 \mathrm{~K} 9, \mathrm{H} 3 \mathrm{~K} 27$, and H3K4 methylation levels, giving more evidence to the mechanisms involved in the hippocampal response to stress [137]. Other studies about the effect of social defeat model on gene transcription in the mouse nucleus accumbens, a brain reward region implicated in depression, revealed important histone modification changes. Levels of repressive H3K9me2 and H3K27me2 were increased at several gene promoters in stresssusceptible animals, including at the promoter of the H3K9 HDM KDM3A. Interestingly, mice resilient to the stress model or treated with conventional antidepressants did not show changes in histone H3 methylation, providing new insights into the molecular mechanisms of depressionlike behaviors and antidepressant activity [119]. Finally, overexpression of the H3K9 HMT SETDB1 in adult forebrain neurons has been shown to induce antidepressant-like phenotypes in mice, probably resulting from changes in NMDA receptor subunit composition [120].

Chromatin remodeling by post-translational modifications of histones is also critical for the induction and stabilization of long-term memory. For example, contextual fear conditioning in adult mice upregulates $\mathrm{H} 3 \mathrm{~K} 4$ methylation, a mark of active transcription, in the hippocampus, at specific promoter regions of Zif268 and Bdnf genes. Mice deficient for the H3K4 HMT MLL displayed deficits in fear memory formation, demonstrating that histone methylation is actively regulated in the hippocampus and facilitates long-term memory formation [121]. H3K4 methylation is also increased at the promoters of GABAergic genes such as Gad1 during human and rodent cerebral cortex maturation [122]. Consistent with this, mice expressing one allele of a truncated Mll transgene showed decreased H3K4 


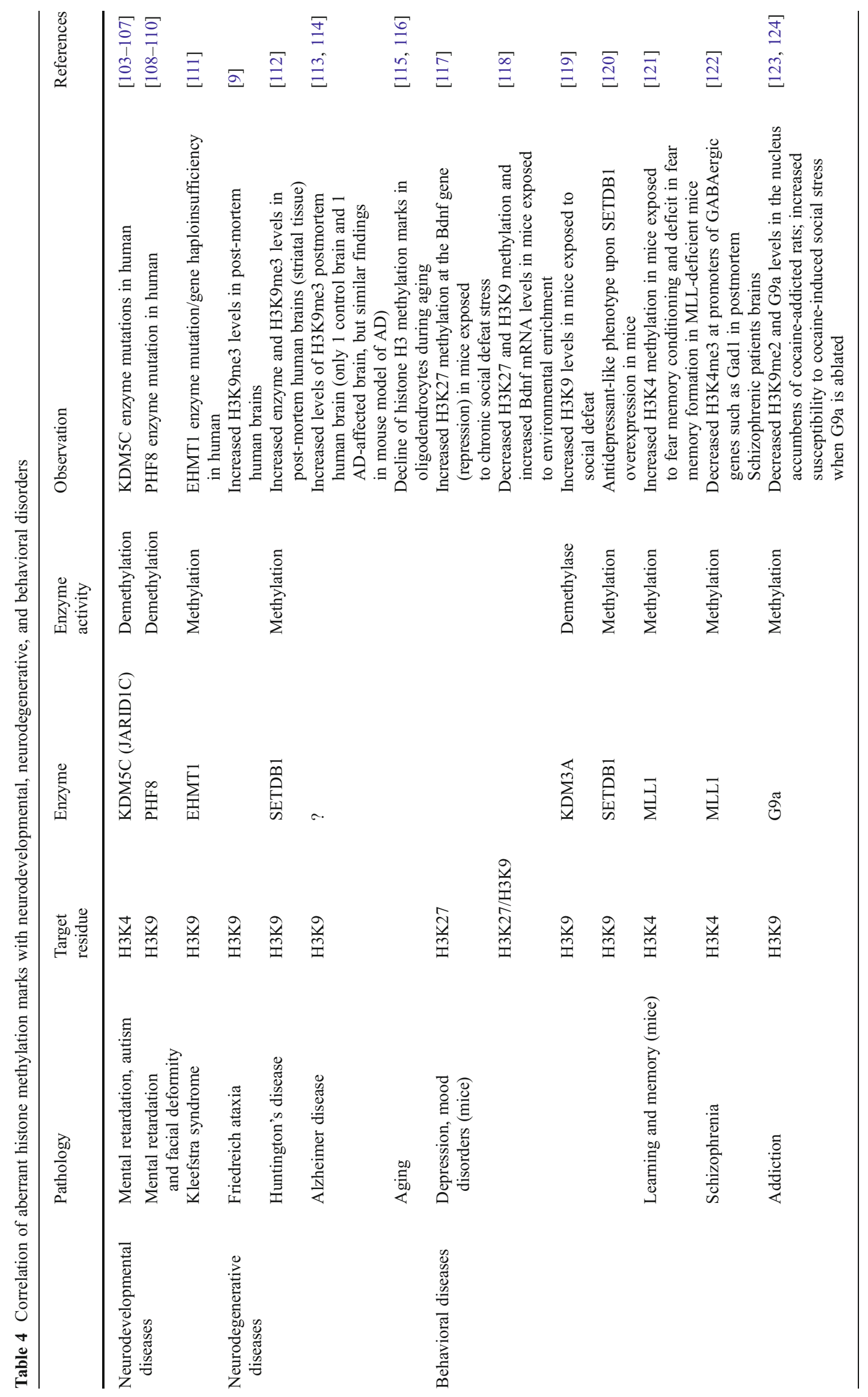


methylation levels at GABAergic gene promoters [122]. Because the brains of schizophrenic patients exhibit decreased levels of $\mathrm{H} 3 \mathrm{~K} 4 \mathrm{me} 3$ at the Gad1 promoter and decreased GAD1 expression, this mechanism may be important for the pathophysiology of schizophrenia [122].

Finally, some studies in mice showed an involvement of H3K9 methylation in drug-induced neuronal gene transcription changes that may regulate structural and behavioral plasticity. Indeed, chronic cocaine administration induces the reduction of H3K9me2 and G9a HMT expression in nucleus accumbens neurons, associated with increased dendritic spine plasticity and enhanced cocaine preference, suggesting a role of histone methylation in the molecular mechanisms of drug addiction [123]. Consistent with these findings, repeated cocaine treatment in mice or ablation of the H3K9 HMT G9a in the nucleus accumbens increased mouse susceptibility to social stress, and overexpression of G9a in the nucleus accumbens rendered mice resilient to stress even after repeated cocaine treatment [124]. A recent study also reports a decrease of $\mathrm{H} 3 \mathrm{~K} 9$ trimethylation at the $B d n f$ promoters II and III after long-term morphine abstinence in the rat brain [138].

\section{Conclusion and Perspectives}

Histone methylation is a major chromatin-remodeling process that regulates transcriptional activity. Depending on the exact location of the methyl group transferred by the HMT, this modification can either lead to transcriptional activation or repression. In addition, the combination of histone methylation with other histone modifications allows the finetuning of transcriptional activity. Consistently, HMTs and HDMs are often found in multiprotein complexes containing other histone modification enzymes such as HATs and HDACs. In particular, the coordinated action of HDACs with HMTs appears as a very frequent event.

Because of its key function in the regulation of transcriptional activity, histone methylation has become a very active area of current investigation, in particular in cancer research, but also more recently in neurobiology. Our knowledge on the functions of histone methylation in the biology of the nervous system is still very sparse; however, it seems clear that in-depth understanding of these functions will lead to major discoveries and advances in medicine. Histone methylation has critical functions in the development of the nervous system. Detection of a wide range of aberrant histone methylations and other histone modifications in diseases of the nervous system (also reviewed in [139]) suggests that chromatin remodeling also plays an important role in these pathologies. However, whether these histone modifications are a cause or a consequence of these diseases is not yet proven, and a lot more work is needed to elucidate the underlying mechanisms of these aberrant histone modifications. From what we currently know, it seems clear that the consideration of combinations of several histone modifications rather than single ones will be a requirement for the success of future therapeutic strategies. There is therefore an enormous need to concentrate our efforts in the integration of coordinated chromatin remodeling mechanisms in our experimental approaches.

Because of their potential involvement in diseases of the nervous system, HMTs and HDMs could constitute innovative therapeutic targets. Several HMT and HDM inhibitors already exist and have shown very promising results, especially in cancer therapy (reviewed in [140]). In addition, the identification of new compounds that specifically target HMTs and HDMs is a very active area of current investigation. We can thus envision the exciting perspective that novel research tools will be soon available to elucidate the functions of histone methylation in neurobiology and that novel compounds may be useful for the treatment of neurological diseases.

Acknowledgments This work is supported by the Swiss National Science Foundation.

Conflicts of interest The authors declare that they have no conflict of interest.

\section{References}

1. Shi Y, Lan F, Matson C, Mulligan P, Whetstine JR, Cole PA, Casero RA, Shi Y (2004) Histone demethylation mediated by the nuclear amine oxidase homolog LSD1. Cell 119:941-953

2. Mosammaparast N, Shi Y (2010) Reversal of histone methylation: biochemical and molecular mechanisms of histone demethylases. Annu Rev Biochem 79:155-179

3. Greer EL, Shi Y (2012) Histone methylation: a dynamic mark in health, disease and inheritance. Nat Rev Genet 13:343-357

4. Han S, Brunet A (2012) Histone methylation makes its mark on longevity. Trends Cell Biol 22:42-49

5. Jacob C, Christen CN, Pereira JA, Somandin C, Baggiolini A, Lötscher P, Ozçelik M, Tricaud N, Meijer D, Yamaguchi T, Matthias P, Suter U (2011) HDAC1 and HDAC2 control the transcriptional program of myelination and the survival of Schwann cells. Nat Neurosci 14:429-436

6. Jacob C, Lebrun-Julien F, Suter U (2011) How histone deacetylases control myelination. Mol Neurobiol 44:303-312

7. Pereira JD, Sansom SN, Smith J, Dobenecker MW, Tarakhovsky A, Livesey FJ (2010) Ezh2, the histone methyltransferase of $\mathrm{PRC} 2$, regulates the balance between self-renewal and differentiation in the cerebral cortex. Proc Natl Acad Sci U S A 107:15957-15962

8. Sher F, Rossler R, Brouwer N, Balasubramaniyan V, Boddeke E, Copray S (2008) Differentiation of neural stem cells into oligodendrocytes: involvement of the polycomb group protein Ezh2. Stem Cells 26:2875-2883

9. Al-Mahdawi S, Pinto RM, Ismail O, Varshney D, Lymperi S, Sandi C, Trabzuni D, Pook M (2008) The Friedreich ataxia GAA 
repeat expansion mutation induces comparable epigenetic changes in human and transgenic mouse brain and heart tissues. Hum Mol Genet 17:735-746

10. Xu J, Andreassi M (2011) Reversible histone methylation regulates brain gene expression and behavior. Horm Behav 59:383392

11. Murray K (1964) The occurrence of epsilon- $N$-methyl lysine in histones. Biochemistry 3:10-15

12. Rea S, Eisenhaber F, O'Carroll D, Strahl BD, Sun ZW, Schmid M, Opravil S, Mechtler K, Ponting CP, Allis CD, Jenuwein T (2000) Regulation of chromatin structure by site-specific histone H3 methyltransferases. Nature 406:593-599

13. Feng Q, Wang H, Ng HH, Erdjument-Bromage H, Tempst P, Struhl K, Zhang Y (2002) Methylation of H3-lysine 79 is mediated by a new family of HMTases without a SET domain. Curr Biol 12:1052-1058

14. Bannister AJ, Kouzarides T (2011) Regulation of chromatin by histone modifications. Cell Res 21:381-395

15. Chang B, Chen Y, Zhao Y, Bruick RK (2007) JMJD6 is a histone arginine demethylase. Science 318:444-447

16. Webby CJ, Wolf A, Gromak N, Dreger M, Kramer H, Kessler B, Nielsen ML, Schmitz C, Butler DS, Yates JR 3rd, Delahunty CM, Hahn P, Lengeling A, Mann M, Proudfoot NJ, Schofield CJ, Bottger A (2009) Jmjd6 catalyses lysyl-hydroxylation of $\mathrm{U} 2 \mathrm{AF} 65$, a protein associated with RNA splicing. Science 325:90-93

17. Wang Y, Wysocka J, Sayegh J, Lee YH, Perlin JR, Leonelli L, Sonbuchner LS, McDonald CH, Cook RG, Dou Y, Roeder RG, Clarke S, Stallcup MR, Allis CD, Coonrod SA (2004) Human PAD4 regulates histone arginine methylation levels via demethylimination. Science 306:279-283

18. Trievel RC (2004) Structure and function of histone methyltransferases. Crit Rev Eukaryot Gene Expr 14:147-169

19. van Leeuwen F, Gafken PR, Gottschling DE (2002) Dot1p modulates silencing in yeast by methylation of the nucleosome core. Cell 109:745-756

20. Min J, Feng Q, Li Z, Zhang Y, Xu RM (2003) Structure of the catalytic domain of human DOT1L, a non-SET domain nucleosomal histone methyltransferase. Cell 112:711-723

21. McBride AE, Silver PA (2001) State of the Arg: protein methylation at arginine comes of age. Cell 106:5-8

22. Wood A, Shilatifard A (2004) Posttranslational modifications of histones by methylation. Adv Protein Chem 67:201-222

23. Chen Y, Yang Y, Wang F, Wan K, Yamane K, Zhang Y, Lei M (2006) Crystal structure of human histone lysine-specific demethylase 1 (LSD1). Proc Natl Acad Sci U S A 103:13956-13961

24. Tsukada Y, Fang J, Erdjument-Bromage H, Warren ME, Borchers CH, Tempst P, Zhang Y (2006) Histone demethylation by a family of JmjC domain-containing proteins. Nature 439:811-816

25. Tian XQ, Fang JY (2007) Current perspectives on histone demethylases. Acta Biochim Biophys Sin 39:81-88

26. Cheung P, Lau P (2005) Epigenetic regulation by histone methylation and histone variants. Mol Endocrinol 19:563-573

27. Krauss V (2008) Glimpses of evolution: heterochromatic histone H3K9 methyltransferases left its marks behind. Genetica 133:93-106

28. Hublitz P, Albert M, Peters AH (2009) Mechanisms of transcriptional repression by histone lysine methylation. Int J Dev Biol 53:335-354

29. Bernstein BE, Humphrey EL, Erlich RL, Schneider R, Bouman P, Liu JS, Kouzarides T, Schreiber SL (2002) Methylation of histone H3 Lys 4 in coding regions of active genes. Proc Natl Acad Sci U S A 99:8695-8700

30. Santos-Rosa H, Schneider R, Bannister AJ, Sherriff J, Bernstein BE, Emre NCT, Schreiber SL, Mellor J, Kouzarides T (2002) Active genes are tri-methylated at K4 of histone H3. Nature 419:407-411
31. Wagner EJ, Carpenter PB (2012) Understanding the language of Lys36 methylation at histone H3. Nat Rev Mol Cell Biol 13:115126

32. Nguyen AT, Zhang Y (2011) The diverse functions of Dot1 and H3K79 methylation. Genes Dev 25:1345-1358

33. Di Lorenzo A, Bedford MT (2011) Histone arginine methylation. FEBS Lett 585:2024-2031

34. Fritsch C, Brown JL, Kassis JA, Muller J (1999) The DNAbinding polycomb group protein pleiohomeotic mediates silencing of a drosophila homeotic gene. Development 126:3905-3913

35. Tillib S, Petruk S, Sedkov Y, Kuzin A, Fujioka M, Goto T, Mazo A (1999) Trithorax- and polycomb-group response elements within an ultrabithorax transcription maintenance unit consist of closely situated but separable sequences. Mol Cell Biol 19:51895202

36. Woo CJ, Kharchenko PV, Daheron L, Park PJ, Kingston RE (2010) A region of the human HOXD cluster that confers polycomb-group responsiveness. Cell 140:99-110

37. Pasini D, Cloos PAC, Walfridsson J, Olsson L, Bukowski JP, Johansen JV, Bak M, Tommerup N, Rappsilber J, Helin K (2010) JARID2 regulates binding of the polycomb repressive complex 2 to target genes in ES cells. Nature 464:306-310

38. Walker E, Chang WY, Hunkapiller J, Cagney G, Garcha K, Torchia J, Krogan NJ, Reiter JF, Stanford WL (2010) Polycomb-like 2 associates with PRC2 and regulates transcriptional networks during mouse embryonic stem cell self-renewal and differentiation. Cell Stem Cell 6:153-166

39. Kuzmichev A, Nishioka K, Erdjument-Bromage H, Tempst P, Reinberg D (2002) Histone methyltransferase activity associated with a human multiprotein complex containing the enhancer of Zeste protein. Genes Dev 16:2893-2905

40. Hawkins PG, Morris KV (2010) Transcriptional regulation of Oct4 by a long non-coding RNA antisense to Oct4-pseudogene 5. Transcription 1:165-175

41. Tsai MC, Manor O, Wan Y, Mosammaparast N, Wang JK, Lan F, Shi Y, Segal E, Chang HY (2010) Long noncoding RNA as modular scaffold of histone modification complexes. Science 329:689-693

42. Wang KC, Yang YW, Liu B, Sanyal A, Corces-Zimmerman R, Chen Y, Lajoie BR, Protacio A, Flynn RA, Gupta RA, Wysocka J, Lei M, Dekker J, Helms JA, Chang HY (2011) A long noncoding RNA maintains active chromatin to coordinate homeotic gene expression. Nature 472:120-124

43. Fukagawa T, Nogami M, Yoshikawa M, Ikeno M, Okazaki T, Takami Y, Nakayama T, Oshimura M (2004) Dicer is essential for formation of the heterochromatin structure in vertebrate cells. Nat Cell Biol 6:784-791

44. Ogawa Y, Sun BK, Lee JT (2008) Intersection of the RNA interference and X-inactivation pathways. Science 320:1336-1341

45. van Wolfswinkel JC, Ketting RF (2010) The role of small noncoding RNAs in genome stability and chromatin organization. $\mathrm{J}$ Cell Sci 123:1825-1839

46. Bartke T, Vermeulen M, Xhemalce B, Robson SC, Mann M, Kouzarides T (2010) Nucleosome-interacting proteins regulated by DNA and histone methylation. Cell 143:470-484

47. Avdic V, Zhang P, Lanouette S, Groulx A, Tremblay V, Brunzelle J, Couture JF (2011) Structural and biochemical insights into MLL1 core complex assembly. Structure 19:101-108

48. Dou Y, Milne TA, Tackett AJ, Smith ER, Fukuda A, Wysocka J, Allis CD, Chait BT, Hess JL, Roeder RG (2005) Physical association and coordinate function of the H3 K4 methyltransferase MLL1 and the H4 K16 acetyltransferase MOF. Cell 121:873-885

49. Paggetti J, Largeot A, Aucagne R, Jacquel A, Lagrange B, Yang XJ, Solary E, Bastie JN, Delva L (2010) Crosstalk between leukemia-associated proteins MOZ and MLL regulates HOX 
gene expression in human cord blood CD34 + cells. Oncogene 29:5019-5031

50. Milne TA, Briggs SD, Brock HW, Martin ME, Gibbs D, Allis CD, Hess JL (2002) MLL targets SET domain methyltransferase activity to Hox gene promoters. Mol Cell 10:1107-1117

51. Wysocka J, Myers MP, Laherty CD, Eisenman RN, Herr W (2003) Human Sin3 deacetylase and trithorax-related Set1/Ash2 histone H3-K4 methyltransferase are tethered together selectively by the cell-proliferation factor HCF-1. Genes Dev 17:896-911

52. Yokoyama A, Wang Z, Wysocka J, Sanyal M, Aufiero DJ, Kitabayashi I, Herr W, Cleary ML (2004) Leukemia protooncoprotein MLL forms a SET1-like histone methyltransferase complex with menin to regulate Hox gene expression. Mol Cell Biol 24:5639-5649

53. Slany RK (2005) Chromatin control of gene expression: mixedlineage leukemia methyltransferase SETs the stage for transcription. Proc Natl Acad Sci U S A 102:14481-14482

54. Schultz DC, Ayyanathan K, Negorev D, Maul GG, Rauscher FJ 3rd (2002) SETDB1: a novel KAP-1-associated histone H3, lysine 9-specific methyltransferase that contributes to HP1mediated silencing of euchromatic genes by KRAB zinc-finger proteins. Genes Dev 16:919-932

55. Yang L, Xia L, Wu DY, Wang H, Chansky HA, Schubach WH, Hickstein DD, Zhang Y (2002) Molecular cloning of ESET, a novel histone $\mathrm{H} 3$-specific methyltransferase that interacts with ERG transcription factor. Oncogene 21:148-152

56. Vaute O, Nicolas E, Vandel L, Trouche D (2002) Functional and physical interaction between the histone methyl transferase Suv39H1 and histone deacetylases. Nucleic Acids Res 30:475481

57. Liu DX, Nath N, Chellappan SP, Greene LA (2005) Regulation of neuron survival and death by p130 and associated chromatin modifiers. Genes Dev 19:719-732

58. Tachibana M, Sugimoto K, Nozaki M, Ueda J, Ohta T, Ohki M, Fukuda M, Takeda N, Niida H, Kato H, Shinkai Y (2002) G9a histone methyltransferase plays a dominant role in euchromatic histone $\mathrm{H} 3$ lysine 9 methylation and is essential for early embryogenesis. Genes Dev 16:1779-1791

59. Hiragami K, Festenstein R (2005) Heterochromatin protein 1: a pervasive controlling influence. Cell Mol Life Sci 62:2711-2726

60. Smallwood A, Esteve PO, Pradhan S, Carey M (2007) Functional cooperation between HP1 and DNMT1 mediates gene silencing. Genes Dev 21:1169-1178

61. Cao R, Wang L, Wang H, Xia L, Erdjument-Bromage H, Tempst P, Jones RS, Zhang Y (2002) Role of histone H3 lysine 27 methylation in polycomb-group silencing. Science 298:10391043

62. Margueron R, Reinberg D (2011) The polycomb complex PRC2 and its mark in life. Nature 469:343-349

63. Endoh M, Endo TA, Endoh T, Isono K, Sharif J, Ohara O, Toyoda $\mathrm{T}$, Ito T, Eskeland R, Bickmore WA, Vidal M, Bernstein BE, Koseki H (2012) Histone H2A mono-ubiquitination is a crucial step to mediate PRC1-dependent repression of developmental genes to maintain ES cell identity. PLoS Genet 8:e1002774

64. Margueron R, Li G, Sarma K, Blais A, Zavadil J, Woodcock CL, Dynlacht BD, Reinberg D (2008) Ezh1 and Ezh2 maintain repressive chromatin through different mechanisms. Mol Cell 32:503-518

65. Xu C, Bian C, Yang W, Galka M, Ouyang H, Chen C, Qiu W, Liu H, Jones AE, MacKenzie F, Pan P, Li SS, Wang H, Min J (2010) Binding of different histone marks differentially regulates the activity and specificity of polycomb repressive complex 2 (PRC2). Proc Natl Acad Sci U S A 107:19266-19271

66. Margueron R, Justin N, Ohno K, Sharpe ML, Son J, Drury WJ 3rd, Voigt P, Martin SR, Taylor WR, De Marco V, Pirrotta V, Reinberg D, Gamblin SJ (2009) Role of the polycomb protein
EED in the propagation of repressive histone marks. Nature 461:762-767

67. Cao R, Zhang Y (2004) SUZ12 is required for both the histone methyltransferase activity and the silencing function of the EEDEZH2 complex. Mol Cell 15:57-67

68. Pasini D, Bracken AP, Jensen MR, Denchi EL, Helin K (2004) Suz12 is essential for mouse development and for EZH2 histone methyltransferase activity. EMBO J 23:4061-4071

69. Kim H, Kang K, Kim J (2009) AEBP2 as a potential targeting protein for polycomb repression complex PRC2. Nucleic Acids Res 37:2940-2950

70. Peng JC, Valouev A, Swigut T, Zhang J, Zhao Y, Sidow A, Wysocka J (2009) Jarid2/Jumonji coordinates control of PRC2 enzymatic activity and target gene occupancy in pluripotent cells. Cell 139:1290-1302

71. Sarma K, Margueron R, Ivanov A, Pirrotta V, Reinberg D (2008) Ezh2 requires PHF1 to efficiently catalyze H3 lysine 27 trimethylation in vivo. Mol Cell Biol 28:2718-2731

72. Walker E, Manias JL, Chang WY, Stanford WL (2011) PCL2 modulates gene regulatory networks controlling self-renewal and commitment in embryonic stem cells. Cell Cycle 10:45-51

73. Shi YJ, Matson C, Lan F, Iwase S, Baba T, Shi Y (2005) Regulation of LSD1 histone demethylase activity by its associated factors. Mol Cell 19:857-864

74. Shi Y, Sawada J, Sui G, el Affar B, Whetstine JR, Lan F, Ogawa H, Luke MP, Nakatani Y, Shi Y (2003) Coordinated histone modifications mediated by a CtBP co-repressor complex. Nature 422:735-738

75. Wang Y, Zhang H, Chen YP, Sun YM, Yang F, Yu WH, Liang J, Sun LY, Yang XH, Shi L, Li RF, Li YY, Zhang Y, Li Q, Yi X, Shang YF (2009) LSD1 is a subunit of the NuRD complex and targets the metastasis programs in breast cancer. Cell 138:660 672

76. Tahiliani M, Mei P, Fang R, Leonor T, Rutenberg M, Shimizu F, Li J, Rao A, Shi Y (2007) The histone H3K4 demethylase SMCX links REST target genes to X-linked mental retardation. Nature 447:601-605

77. Zhang DZ, Yoon HG, Wong JM (2005) JMJD2A is a novel NCoR-interacting protein and is involved in repression of the human transcription factor achaete scute-like homologue 2 (ASCL2/Hash2). Mol Cell Biol 25:6404-6414

78. Hayakawa T, Ohtani Y, Hayakawa N, Shinmyozu K, Saito M, Ishikawa F, Nakayama J (2007) RBP2 is an MRG15 complex component and down-regulates intragenic histone $\mathrm{H} 3$ lysine 4 methylation. Genes Cells 12:811-826

79. Metzger E, Wissmann M, Yin N, Muller JM, Schneider R, Peters AH, Gunther T, Buettner R, Schule R (2005) LSD1 demethylates repressive histone marks to promote androgen-receptordependent transcription. Nature 437:436-439

80. Garcia-Bassets I, Kwon YS, Telese F, Prefontaine GG, Hutt KR, Cheng CS, Ju BG, Ohgi KA, Wang J, Escoubet-Lozach L, Rose DW, Glass CK, Fu XD, Rosenfeld MG (2007) Histone methylation-dependent mechanisms impose ligand dependency for gene activation by nuclear receptors. Cell 128:505-518

81. Jepsen K, Solum D, Zhou T, McEvilly RJ, Kim HJ, Glass CK, Hermanson O, Rosenfeld MG (2007) SMRT-mediated repression of an $\mathrm{H} 3 \mathrm{~K} 27$ demethylase in progression from neural stem cell to neuron. Nature 450:415-419

82. Burgold T, Spreafico F, De Santa F, Totaro MG, Prosperini E, Natoli G, Testa G (2008) The histone H3 lysine 27-specific demethylase Jmjd3 is required for neural commitment. PLoS One 3:e3034

83. Estaras C, Akizu N, Garcia A, Beltran S, de la Cruz X, MartinezBalbas MA (2012) Genome-wide analysis reveals that Smad3 and JMJD3 HDM co-activate the neural developmental program. Development 139:2681-2691 
84. Lim DA, Huang YC, Swigut T, Mirick AL, Garcia-Verdugo JM, Wysocka J, Ernst P, Alvarez-Buylla A (2009) Chromatin remodelling factor M111 is essential for neurogenesis from postnatal neural stem cells. Nature 458:529-533

85. Patel SR, Kim D, Levitan I, Dressler GR (2007) The BRCTdomain containing protein PTIP links PAX2 to a histone H3, lysine 4 methyltransferase complex. Dev Cell 13:580-592

86. Ballas N, Grunseich C, Lu DD, Speh JC, Mandel G (2005) REST and its corepressors mediate plasticity of neuronal gene chromatin throughout neurogenesis. Cell 121:645-657

87. Abrajano JJ, Qureshi IA, Gokhan S, Zheng DY, Bergman A, Mehler MF (2009) REST and CoREST modulate neuronal subtype specification, maturation and maintenance. PLoS One 4: e7936

88. Sen N, Snyder SH (2011) Neurotrophin-mediated degradation of histone methyltransferase by $S$-nitrosylation cascade regulates neuronal differentiation. Proc Natl Acad Sci U S A 108:2017820183

89. Asensio-Juan E, Gallego C, Martinez-Balbas MA (2012) The histone demethylase PHF8 is essential for cytoskeleton dynamics. Nucleic Acids Res 40:9429-9440

90. Tan SL, Nishi M, Ohtsuka T, Matsui T, Takemoto K, KamioMiura A, Aburatani H, Shinkai Y, Kageyama R (2012) Essential roles of the histone methyltransferase ESET in the epigenetic control of neural progenitor cells during development. Development 139:3806-3816

91. Weng MK, Zimmer B, Poltl D, Broeg MP, Ivanova V, Gaspar JA, Sachinidis A, Wullner U, Waldmann T, Leist M (2012) Extensive transcriptional regulation of chromatin modifiers during human neurodevelopment. PLoS One 7:e36708

92. Sher F, Boddeke E, Olah M, Copray S (2012) Dynamic changes in Ezh2 gene occupancy underlie its involvement in neural stem cell self-renewal and differentiation towards oligodendrocytes. PLoS One 7:e40399

93. Shen S, Li J, Casaccia-Bonnefil P (2005) Histone modifications affect timing of oligodendrocyte progenitor differentiation in the developing rat brain. J Cell Biol 169:577-589

94. Abrajano JJ, Qureshi IA, Gokhan S, Zheng D, Bergman A, Mehler MF (2009) Differential deployment of REST and CoREST promotes glial subtype specification and oligodendrocyte lineage maturation. PLoS One 4:e7665

95. Heinen A, Tzekova N, Graffmann N, Torres KJ, Uhrberg M, Hartung HP, Kury P (2012) Histone methyltransferase enhancer of zeste homolog 2 regulates Schwann cell differentiation. Glia 60:1696-1708

96. Heinen A, Kremer D, Gottle P, Kruse F, Hasse B, Lehmann H, Hartung HP, Kury P (2008) The cyclin-dependent kinase inhibitor p57kip2 is a negative regulator of Schwann cell differentiation and in vitro myelination. Proc Natl Acad Sci U S A 105:87488753

97. Song MR, Ghosh A (2004) FGF2-induced chromatin remodeling regulates CNTF-mediated gene expression and astrocyte differentiation. Nat Neurosci 7:229-235

98. Barber SA, Gama L, Dudaronek JM, Voelker T, Tarwater PM, Clements JE (2006) Mechanism for the establishment of transcriptional HIV latency in the brain in a simian immunodeficiency virus-macaque model. J Infect Dis 193:963-970

99. Marban C, Suzanne S, Dequiedt F, de Walque S, Redel L, Van Lint C, Aunis D, Rohr O (2007) Recruitment of chromatinmodifying enzymes by CTIP2 promotes HIV-1 transcriptional silencing. EMBO J 26:412-423

100. Cherrier T, Suzanne S, Redel L, Calao M, Marban C, Samah B, Mukerjee R, Schwartz C, Gras G, Sawaya BE, Zeichner SL, Aunis D, Van Lint C, Rohr O (2009) p21(WAF1) gene promoter is epigenetically silenced by CTIP2 and SUV39H1. Oncogene 28:3380-3389
101. Le Douce V, Colin L, Redel L, Cherrier T, Herbein G, Aunis D, Rohr O, Van Lint C, Schwartz C (2012) LSD1 cooperates with CTIP2 to promote HIV-1 transcriptional silencing. Nucleic Acids Res 40:1904-1915

102. Saijo K, Winner B, Carson CT, Collier JG, Boyer L, Rosenfeld MG, Gage FH, Glass CK (2009) A Nurr1/CoREST pathway in microglia and astrocytes protects dopaminergic neurons from inflammation-induced death. Cell 137:47-59

103. Jensen LR, Amende M, Gurok U, Moser B, Gimmel V, Tzschach A, Janecke AR, Tariverdian G, Chelly J, Fryns JP, Van Esch H, Kleefstra T, Hamel B, Moraine C, Gecz J, Turner G, Reinhardt R, Kalscheuer VM, Ropers HH, Lenzner S (2005) Mutations in the JARID1C gene, which is involved in transcriptional regulation and chromatin remodeling, cause X-linked mental retardation. Am J Hum Genet 76:227-236

104. Santos C, Rodriguez-Revenga L, Madrigal I, Badenas C, Pineda M, Mila M (2006) A novel mutation in JARID1C gene associated with mental retardation. Eur J Hum Genet 14:583-586

105. Tzschach A, Lenzner S, Moser B, Reinhardt R, Chelly J, Fryns JP, Kleefstra T, Raynaud M, Turner G, Ropers HH, Kuss A, Jensen LR (2006) Novel JARID1C/SMCX mutations in patients with $\mathrm{X}$-linked mental retardation. Hum Mutat 27:389

106. Adegbola A, Gao H, Sommer S, Browning M (2008) A novel mutation in JARID1C/SMCX in a patient with autism spectrum disorder (ASD). Am J Med Genet A 146A:505-511

107. Santos-Reboucas CB, Fintelman-Rodrigues N, Jensen LR, Kuss AW, Ribeiro MG, Campos M Jr, Santos JM, Pimentel MM (2011) A novel nonsense mutation in KDM5C/JARID1C gene causing intellectual disability, short stature and speech delay. Neurosci Lett 498:67-71

108. Laumonnier F, Holbert S, Ronce N, Faravelli F, Lenzner S, Schwartz CE, Lespinasse J, Van Esch H, Lacombe D, Goizet C, Phan-Dinh Tuy F, van Bokhoven H, Fryns JP, Chelly J, Ropers HH, Moraine C, Hamel BC, Briault S (2005) Mutations in PHF8 are associated with $\mathrm{X}$ linked mental retardation and cleft lip/cleft palate. J Med Genet 42:780-786

109. Koivisto AM, Ala-Mello S, Lemmela S, Komu HA, Rautio J, Jarvela I (2007) Screening of mutations in the PHF8 gene and identification of a novel mutation in a Finnish family with XLMR and cleft lip/cleft palate. Clin Genet 72:145-149

110. Abidi FE, Miano MG, Murray JC, Schwartz CE (2007) A novel mutation in the PHF8 gene is associated with X-linked mental retardation with cleft lip/cleft palate. Clin Genet 72:19-22

111. Kleefstra T, Brunner HG, Amiel J, Oudakker AR, Nillesen WM, Magee A, Genevieve D, Cormier-Daire V, van Esch H, Fryns JP, Hamel BC, Sistermans EA, de Vries BB, van Bokhoven H (2006) Loss-of-function mutations in euchromatin histone methyl transferase 1 (EHMT1) cause the 9q34 subtelomeric deletion syndrome. Am J Hum Genet 79:370-377

112. Ryu H, Lee J, Hagerty SW, Soh BY, McAlpin SE, Cormier KA, Smith KM, Ferrante RJ (2006) ESET/SETDB1 gene expression and histone $\mathrm{H} 3$ (K9) trimethylation in Huntington's disease. Proc Natl Acad Sci U S A 103:19176-19181

113. Chouliaras L, Rutten BP, Kenis G, Peerbooms O, Visser PJ, Verhey F, van Os J, Steinbusch HW, van den Hove DL (2010) Epigenetic regulation in the pathophysiology of Alzheimer's disease. Prog Neurobiol 90:498-510

114. Lithner C, Hernandez C, Nordberg A, Sweatt D (2009) Epigenetic changes related to beta-amyloid - implications for Alzheimer's disease. Alzheimers Dement J Alzheimers Assoc 5:P304

115. Shen SM, Liu AX, Li JD, Wolubah C, Casaccia-Bonnefil P (2008) Epigenetic memory loss in aging oligodendrocytes in the corpus callosum. Neurobiol Aging 29:452-463

116. Shen SM, Sandoval J, Swiss VA, Li JD, Dupree J, Franklin RJM, Casaccia-Bonnefil P (2008) Age-dependent epigenetic control of 
differentiation inhibitors is critical for remyelination efficiency. Nat Neurosci 11:1024-1034

117. Tsankova NM, Berton O, Renthal W, Kumar A, Neve RL, Nestler EJ (2006) Sustained hippocampal chromatin regulation in a mouse model of depression and antidepressant action. Nat Neurosci 9:519-525

118. Kuzumaki N, Ikegami D, Tamura R, Hareyama N, Imai S, Narita M, Torigoe K, Niikura K, Takeshima H, Ando T, Igarashi K, Kanno J, Ushijima T, Suzuki T, Narita M (2011) Hippocampal epigenetic modification at the brain-derived neurotrophic factor gene induced by an enriched environment. Hippocampus 21:127132

119. Wilkinson MB, Xiao G, Kumar A, LaPlant Q, Renthal W, Sikder D, Kodadek TJ, Nestler EJ (2009) Imipramine treatment and resiliency exhibit similar chromatin regulation in the mouse nucleus accumbens in depression models. J Neurosci 29:7820-7832

120. Jiang Y, Jakovcevski M, Bharadwaj R, Connor C, Schroeder FA, Lin CL, Straubhaar J, Martin G, Akbarian S (2010) Setdb1 histone methyltransferase regulates mood-related behaviors and expression of the NMDA receptor subunit NR2B. J Neurosci 30:7152-7167

121. Gupta S, Kim SY, Artis S, Molfese DL, Schumacher A, Sweatt JD, Paylor RE, Lubin FD (2010) Histone methylation regulates memory formation. J Neurosci 30:3589-3599

122. Huang HS, Matevossian A, Whittle C, Kim SY, Schumacher A, Baker SP, Akbarian S (2007) Prefrontal dysfunction in schizophrenia involves mixed-lineage leukemia 1-regulated histone methylation at GABAergic gene promoters. J Neurosci 27:11254-11262

123. Maze I, Covington HE 3rd, Dietz DM, LaPlant Q, Renthal W, Russo SJ, Mechanic M, Mouzon E, Neve RL, Haggarty SJ, Ren Y, Sampath SC, Hurd YL, Greengard P, Tarakhovsky A, Schaefer A, Nestler EJ (2010) Essential role of the histone methyltransferase G9a in cocaine-induced plasticity. Science 327:213-216

124. Covington HE 3rd, Maze I, Sun H, Bomze HM, DeMaio KD, Wu EY, Dietz DM, Lobo MK, Ghose S, Mouzon E, Neve RL, Tamminga CA, Nestler EJ (2011) A role for repressive histone methylation in cocaine-induced vulnerability to stress. Neuron 71:656-670

125. Xu J, Deng X, Disteche CM (2008) Sex-specific expression of the X-linked histone demethylase gene Jarid1c in brain. PLoS One 3:e2553

126. Iwase S, Lan F, Bayliss P, de la Torre-Ubieta L, Huarte M, Qi HH, Whetstine JR, Bonni A, Roberts TM, Shi Y (2007) The X-linked mental retardation gene SMCX/JARID1C defines a family of histone H3 lysine 4 demethylases. Cell 128:1077-1088

127. Qi HH, Sarkissian M, Hu GQ, Wang Z, Bhattacharjee A, Gordon DB, Gonzales M, Lan F, Ongusaha PP, Huarte M, Yaghi NK, Lim
H, Garcia BA, Brizuela L, Zhao K, Roberts TM, Shi Y (2010) Histone H4K20/H3K9 demethylase PHF8 regulates zebrafish brain and craniofacial development. Nature 466:503-507

128. Balemans MC, Huibers MM, Eikelenboom NW, Kuipers AJ, van Summeren RC, Pijpers MM, Tachibana M, Shinkai Y, van Bokhoven H, Van der Zee CE (2010) Reduced exploration, increased anxiety, and altered social behavior: autistic-like features of euchromatin histone methyltransferase 1 heterozygous knockout mice. Behav Brain Res 208:47-55

129. Fritsch L, Robin P, Mathieu JRR, Souidi M, Hinaux H, Rougeulle C, Harel-Bellan A, Ameyar-Zazoua M, Ait-Si-Ali S (2010) A subset of the histone H3 lysine 9 methyltransferases Suv39h1, G9a, GLP, and SETDB1 participate in a multimeric complex. Mol Cell 37:46-56

130. Schaefer A, Sampath SC, Intrator A, Min A, Gertler TS, Surmeier DJ, Tarakhovsky A, Greengard P (2009) Control of cognition and adaptive behavior by the GLP/G9a epigenetic suppressor complex. Neuron 64:678-691

131. Schmucker S, Puccio H (2010) Understanding the molecular mechanisms of Friedreich's ataxia to develop therapeutic approaches. Hum Mol Genet 19:R103-R110

132. Li SH, Cheng AL, Zhou H, Lam S, Rao M, Li H, Li XJ (2002) Interaction of Huntington disease protein with transcriptional activator Sp1. Mol Cell Biol 22:1277-1287

133. Dunah AW, Jeong H, Griffin A, Kim YM, Standaert DG, Hersch SM, Mouradian MM, Young AB, Tanese N, Krainc D (2002) Sp1 and TAFII130 transcriptional activity disrupted in early Huntington's disease. Science 296:2238-2243

134. Yu ZX, Li SH, Nguyen HP, Li XJ (2002) Huntingtin inclusions do not deplete polyglutamine-containing transcription factors in HD mice. Hum Mol Genet 11:905-914

135. Williams TL, Serpell LC (2011) Membrane and surface interactions of Alzheimer's $A \beta$ peptide-insights into the mechanism of cytotoxicity. FEBS J 278:3905-3917

136. Duman RS, Monteggia LM (2006) A neurotrophic model for stress-related mood disorders. Biol Psychiatry 59:1116-1127

137. Hunter RG, McCarthy KJ, Milne TA, Pfaff DW, McEwen BS (2009) Regulation of hippocampal H3 histone methylation by acute and chronic stress. Proc Natl Acad Sci U S A 106:20912-20917

138. Mashayekhi FJ, Rasti M, Rahvar M, Mokarram P, Namavar MR, Owji AA (2012) Expression levels of the BDNF gene and histone modifications around its promoters in the ventral tegmental area and locus ceruleus of rats during forced abstinence from morphine. Neurochem Res 37:1517-1523

139. Jakovcevski M, Akbarian S (2012) Epigenetic mechanisms in neurological disease. Nat Med 18:1194-1204

140. Kelly TK, De Carvalho DD, Jones PA (2010) Epigenetic modifications as therapeutic targets. Nat Biotechnol 28:1069-1078 